\title{
GIFTED CHILD IN KINDERGARTEN - ASSESSMENT PITFALLS
}

\begin{abstract}
Issues and considerations raised in the article are related to the identification (assessment) of gifted children, often described in literature, in relation to selected theories of ability. It is very likely that a gifted child characterized by the specificity of early childhood, commonly defined as intelligent, with high cognitive abilities, will abandon its innate, unique potential, entangling in various types of "problems", taking on the features of the syndrome of inadequate school achievements, etc. in the future, as a result of adverse environmental impacts, the coincidence of events. The individual case studies presented in the article are intended to illustrate the significance of individual impacts on a gifted child of preschool age, due to the specific developmental peculiarities of this period.
\end{abstract}

Keywords: gifted child; talented child; kindergarten; pre-school teacher; diagnosis.

Everyone is different and that's exciting. Maria Nurowska, There will be no other life

\section{Introduction}

According to the CSO report Education and education system, in the 2017/2018 school year, a total of 1,361,183 children attended kindergartens in Poland (Central Statistical Office, Warsaw, Gdansk 2018). The figures provide some measurable background for reflection on the topic of pre-school gifted children, who stand out in some way among the rest of their peers. For various reasons they need a different type of educational interaction with their teachers who apart from parents, are the first line of support for the child's development in the extremely important, often crucial, period of early childhood. Any such support requires prior identification of the child. In the literature, many concepts are presented that indicate some special features of such children: 'innateaptitude', 'abilities', 'talents', 'real abilities', 'specific abilities', 'talent', 'creative abilities', 'exceptional abilities', 'wonderful children',

* PhD Elżbieta Kwiatkowska, the Cardinal Stefan Wyszyński University in Warsaw, Poland, Faculty of Education; e-mail: e.kwiatkowska@uksw.edu.pl. 
'genius' and others. The rest of the analysis will be based on a conceptual division into: "gifted" - understood as higher general abilities of children, combined with intelligence in the literature as opposed to "talented" - understood as with special, directional abilities, revealed in activities related to a specific area of child activity (Limont, 2012, pp. 16-22). Hence, the general goal of the considerations is to look for pedagogical and organizational solutions that will optimize support for the development of gifted children.

When performing this type of conventional categorization of talent, and individuality of a person, I would like to emphasize that the types of simplifications are constructed for the theoretical analyses that allow verifying the situation of children of a certain age quite broadly. In turn, all individual, practical educational impacts on the child should individually focus on their holistic support, in full acceptance of their developmental features.

The percentage of gifted children in the entire children's population is between 3 and 10\%, depending on the methodology adopted (Renzulli, 2000) and the terminological approach (Gardner, 1983; 2002; Sternberg, 1986). According to Wiesława Limont (2012, pp. 18-19), 2-3\% of the population are very gifted. People described as gifted constitute about $13 \%$ of the population, while the most are average, about $34 \%$ of the population. In Poland, $2 \%$ or 27,223 children attending kindergartens in the 2017/2018 school year were considered highly gifted. In my opinion, this is a great number of kids, who, regardless of the adopted model of ability, are already a kind of human capital, which should be developed, supported and nurtured for the good of the general population. The whole history of humanity, its progress, civilization, culture is based on outstanding individuals who are brave, wise, interesting, dreaming, seeking, seeing the world differently "than most". Reflection on the educational process defined as an unusual meeting between a teacher and a gifted child in kindergarten, can be useful in creating a supportive environment for a gifted child.

\section{Gifted children - theoretical outline}

The very identification of a gifted child appears to a real challenge. Children continue changing in areas of social communication, including speaking, cognitive, emotional development. The process of identification also needs to consider changes and the resulting opportunities in child's physical development).

The literature presents various types of characteristics or typologies of indicators that can help identify a gifted child. Data coming from older publications indicate that physical features can distinguish gifted children. Many researchers, especially in the eighties and nineties of the twentieth century, sought more specific clues that could help identify gifted children. According to them, some gifted children display a higher level of energy put into various tasks (Feldhusen, 1989). Other researchers associated giftedness with a faster physical development of gifted individuals when 
compared to their peers, while others pointed to the inverse relationship, based on biographical analyses of well-known, outstanding people who, despite some deficits in physical appearance, were described as gifted. Perhaps due to the lack of unambiguous empirical evidence for linking physicality with a gifted child, another consideration can be worth taking into account. Acceleration of development is a phenomenon that appeared along with the development of modern societies, with the improvement of economic, social and especially living conditions. This is a phenomenon of acceleration development, primarily biological, compared to previous generations ( $P W N$ Encyclopedia). In practice, this means that children grow faster, have their teeth at a younger age, ossification centers appear earlier in them, etc. than in their parents, grandparents, etc. It is worth noting that the phenomenon of acceleration is associated primarily with the physical or biological side of man, but does not cause faster emotional or social development The problem of acceleration in the context of identifying gifted kindergarten children is discussed in Dimitrios Papadopoulus' (2016) research, who indicates that it can be expressed, inter alia, through an earlier readiness for pre-school education of a child, the socalled "double promotion", enabling the child to move to a group older than their age peers, as well as successes in areas related to the child's accelerated development and others.

In the theoretical outline of the considerations, it is worth recalling the multiple intelligence model, which presents human potential in eight categories (logicalmathematical, linguistic, natural, musical, spatial, kinesthetic, interpersonal and intrapersonal intelligence). This concept is an example of a model of specific abilities, and intelligence that according to Gardner is the ability to solve problems, produce new ideas or products. It means we can associate intelligence with the creative abilities of the individual (Gardner, 2002).

Renzulli's (2005) three-ring conception of giftedness presents capabilities as a structure of interrelated and interacting components. He made a basic categorization for giftedness useful in school learning and for creative and productive abilities. Due to the complexity of the concept of giftedness, Renzulli emphasized that and conditioning of individual development that is broader than the intelligence quotient should be taken into account. His three-ring giftedness model distinguishes three main fields of interaction: (a) above-average general abilities, usually expressed through intelligence tests and included in this category of directional (broadly understood) talents, (b) commitment to the task, total dedication to the activity, high concentration, which can be manifested even by the youngest children. Maria Montessori (2005; 2014), among others, wrote about it, formulating the concept of attention polarization. Creative abilities (c) are manifested in cognitive curiosity, fluidity and flexibility of thinking, and openness to new experiences. Renzulli formulated the concept of "capacity-related behaviors" that can indicate the student's potential. He believes that appropriate educational impacts can transform this noticeable potential into abilities that have even the 
hallmarks of being outstanding. Among the non-intellectual factors that can support the development of a child's abilities, he lists optimism, courage, passion for a topic or discipline, empathy, physical and mental energy and vision (intuition /destiny) (Limont, 2012, pp. 54-59).

The concept of Robert J. Sternberg is another systemic ability model recognized in the literature. Like Renzulli, he believes that human intelligence cannot be determined solely by the intelligence quotient. He pointed out that in the context of ability analysis, „achieved success” is more important than the individual's potential. Based on the conclusions, he formulated the concept of intelligence of success, which W. Limont (2012, p. 60) describes as "the ability to achieve complex goals in a specific socio-cultural environment by properly using the strengths and weaknesses of one's personality and talents." Therefore, the key role here is the ability to adapt to the surrounding environment, which also takes place through "its modification and creating the most favorable context for own development, with the possibility of choosing another, better solution" (Limont (2012, p. 60). This approach is extremely far from the model based solely on IQ level measurement that has been functioning for years. Sternberg, in his WICS model points to four elements that characterize gifted persons: wisdom, intelligence, creativity and synthesized. The author of the concept indicates that the wisdom component is one of the most important features of gifted people. We can find maturity and experience in the semantics of the word wisdom, because its source is, among others, "the ability to dispose of hidden knowledge about yourself, other people and a specific situational context" (Limont, 2012, p. 61). Intelligence and creativity are components that appear in many concepts. They differ in terms of detailed or expanded definitions and the context adopted, but the core of meaning, the area they describe, is common. The fourth component of the model is designed to combine, synthesize the other three. The balance and harmony between them are probably conditions for the realization of human abilities in the most favorable conditions for him.

The issue of gifted children from the perspective of practical work of the teacher looks slightly different. In her studies on gifted children, Cagla Gur (2011, p. 494) reviewed research in this field, grouping them into four categories: physical characteristics (discussed in this article in the context of development acceleration), language development, cognitive development, and social development. Preschool children, assigned in the study to the category of gifted children, ask problem questions, talk about motives, goals of undertaken actions, have a rich vocabulary, put together their own stories, are characterized by a great sense of humor. They speak in an elaborate, clear manner, understandable to the recipients. They can creatively use the speech organs, playing with it while performing onomatopeic simulations (e.g. imitating wind, tree noise and other sounds).

Gifted children are usually more open to new experiences, curious about the world, looking for detailed information, exploring the topic that interests them, 
devoting certain activities to much more time than others. Some studies indicate that gifted children are bored more often (Kwiatkowska, 2018), require individual attention of the teacher, perform specific tasks faster, master reading and writing skills in preschool age.

The development and social functioning of gifted children are exposed to the negative side effects of higher levels of certain skills or traits. High commitment and above-average knowledge or skill can be an obstacle to optimal interaction with other children from the kindergarten group, becoming a field for conflicts and indirectly a reason for alienation, independence, loneliness of a capable individual. The role and importance of teacher's activities in supporting such a child is invaluable. This is an individual work, often carried out in difficult conditions, in large groups, without the optimal support of other adults. It is about both organizational and substantive support in identifying and supporting gifted children, not forgetting about children requiring special educational impact, burdened with a certain health problem (Kwiatkowska, 2018). The reflection that appears when developing this type of analysis and consideration is always very similar. On the road to perfection, in order to develop, support and improve a pre-schooler in an already functioning, organized education system (currently a group of children in the kindergarten can have 25 pupils per one teacher and a teacher aid who does not need pedagogical qualifications), in the author's opinion, organizational changes aimed at increasing the mandatory number of teachers (people with degrees in pedagogy, permanently working with children) to a minimum of 2 (and a person called "teacher aid") should be seriously considered.

\section{Research Design, Procedure and Methods}

The study described below concerns individual cases of gifted preschool children presented from the perspective of their teachers. The main goal of the research is to verify the hypothesis that at the stage of pre-school education, a gifted child who has cognitive capabilities that outweigh most of his peers, needs intentional support from the environment, important adults, parents, or teachers to fully use his potential. However, the lack of support from adults lead to lowering the child's potential and the occurrence of difficulties that can disrupt his optimal development. The indirect goal of the article is to draw the readers' attention to the need for systematic, additional, intentional support of gifted children in kindergarten.

Looking for solutions that would optimize pre-school education, I have been conducting longitudinal qualitative research in this area. I stay in touch with inservice teachers. I asked them for a structured interview about a gifted child in a preschool group. In September and October 2019, I interviewed teachers and obtained 3 characteristics of children attending a kindergarten in a small village and 8 children attending a kindergarten in Warsaw, the capital city of Poland 
with more than 2,000,000 residents. Qualitative analyses showed no statistically significant demographic differences.

The study involved 11 teachers, young people with less than 5 years of work experience. 3 of them work in public kindergartens, 8 in private ones.

For the purposes of research two diagnostic instruments were developed, based on conducted literature analyzes and references to the theoretical part of this article. They made it possible for teachers to observe children and for the author to conduct structured interviews with teachers focused on the profiled characteristics of children, placed by them in the category of "gifted".

The first instrument is a questionnaire with a list of 23 characteristics of gifted children (Table 1) that allows to determine how many of them co-occur simultaneously. Teachers were asked to identify gifted children in their groups and indicate which of these 23 characteristics they exhibited. The results of this stage became the basis for the second part of the research. It consisted of an in-depth, standardized interviews with teachers, aimed at deepening understanding of the wider situation and functioning of gifted children in kindergarten. The study was qualitative, based on content analysis. The article presents in detail the cases of three children who obtained the most, the least and the average number of indications in the first stage of the research.

\section{Research Results and Discussion}

The results of first part of the research are the table below. It shows how the teacher's indications for individual children were distributed. At this stage, teachers also had an opportunity to provide additonal information about the child in the form of an open statement.

Table 1: Teachers' indications about the features of gifted children

\begin{tabular}{|l|c|c|c|c|c|c|c|c|c|c|c|c|}
\hline \multicolumn{1}{|c|}{ Child } & 1 & 2 & 3 & 4 & 5 & 6 & 7 & 8 & 9 & 10 & 11 & $\begin{array}{c}\text { Number } \\
\text { of } \\
\text { responses }\end{array}$ \\
\hline Age & 6 & 7 & 4 & 6 & 4 & 4 & 3 & 4 & 5 & 6 & 4 & $\mathrm{~N}=11$ \\
\hline Sex & $\mathrm{f}$ & $\mathrm{f}$ & $\mathrm{f}$ & $\mathrm{m}$ & $\mathrm{m}$ & $\mathrm{f}$ & $\mathrm{m}$ & $\mathrm{f}$ & $\mathrm{m}$ & $\mathrm{m}$ & $\mathrm{M}$ & \\
\hline $\begin{array}{l}\text { cognitively } \\
\text { developed - rea- } \\
\text { soning at a level } \\
\text { exceeding peers }\end{array}$ & $\mathrm{x}$ & $\mathrm{x}$ & $\mathrm{x}$ & $\mathrm{x}$ & $\mathrm{x}$ & $\mathrm{x}$ & $\mathrm{X}$ & $\mathrm{x}$ & $\mathrm{x}$ & $\mathrm{x}$ & $\mathrm{X}$ & 11 \\
\hline $\begin{array}{l}\text { can see connec- } \\
\text { tions between } \\
\text { facts and objects }\end{array}$ & $\mathrm{x}$ & $\mathrm{x}$ & $\mathrm{x}$ & $\mathrm{x}$ & $\mathrm{x}$ & $\mathrm{x}$ & $\mathrm{X}$ & $\mathrm{x}$ & $\mathrm{x}$ & $\mathrm{x}$ & $\mathrm{X}$ & 11 \\
\hline
\end{tabular}




\begin{tabular}{|c|c|c|c|c|c|c|c|c|c|c|c|c|}
\hline Child & 1 & 2 & 3 & 4 & 5 & 6 & 7 & 8 & 9 & 10 & 11 & $\begin{array}{c}\begin{array}{c}\text { Number } \\
\text { of } \\
\text { responses }\end{array}\end{array}$ \\
\hline $\begin{array}{l}\text { has greater } \\
\text { knowledge (than } \\
\text { peers) }\end{array}$ & & $\mathrm{x}$ & $\mathrm{x}$ & $\mathrm{x}$ & $\mathrm{x}$ & $\mathrm{x}$ & $\mathrm{X}$ & $\mathrm{x}$ & $\mathrm{x}$ & $\mathrm{x}$ & $\mathrm{X}$ & 10 \\
\hline is creative & $\mathrm{x}$ & $\mathrm{x}$ & $\mathrm{x}$ & $\mathrm{x}$ & $\mathrm{x}$ & $\mathrm{x}$ & $X$ & & $\mathrm{x}$ & $\mathrm{x}$ & $X$ & 10 \\
\hline $\begin{array}{l}\text { has the ability to } \\
\text { concentrate and } \\
\text { Focus }\end{array}$ & $\mathrm{x}$ & $\mathrm{x}$ & $\mathrm{x}$ & & $\mathrm{x}$ & $\mathrm{x}$ & $\mathrm{X}$ & $\mathrm{x}$ & $\mathrm{x}$ & $\mathrm{x}$ & $\mathrm{X}$ & 10 \\
\hline $\begin{array}{l}\text { can think } \\
\text { abstractly }\end{array}$ & $\mathrm{x}$ & $\mathrm{x}$ & $\mathrm{x}$ & & $\mathrm{x}$ & $\mathrm{x}$ & $\mathrm{X}$ & & $\mathrm{x}$ & $\mathrm{x}$ & $\mathrm{X}$ & 9 \\
\hline $\begin{array}{l}\text { has good } \\
\text { memory }\end{array}$ & $\mathrm{x}$ & $\mathrm{x}$ & $\mathrm{x}$ & & $\mathrm{x}$ & $\mathrm{x}$ & $\mathrm{X}$ & $\mathrm{x}$ & & $\mathrm{x}$ & $\mathrm{X}$ & 9 \\
\hline $\begin{array}{l}\text { starts, initiates } \\
\text { relationships }\end{array}$ & & $\mathrm{x}$ & & $\mathrm{x}$ & $\mathrm{x}$ & $\mathrm{x}$ & $\mathrm{X}$ & & & & $\mathrm{X}$ & 6 \\
\hline $\begin{array}{l}\text { physically more } \\
\text { developed (than } \\
\text { peers) }\end{array}$ & $\mathrm{x}$ & & & & $\mathrm{x}$ & $\mathrm{x}$ & $\mathrm{X}$ & & & & $\mathrm{X}$ & 5 \\
\hline $\begin{array}{l}\text { has very good } \\
\text { problem solving } \\
\text { skills }\end{array}$ & & & & $\mathrm{x}$ & $\mathrm{x}$ & & & & $\mathrm{x}$ & $\mathrm{x}$ & $\mathrm{X}$ & 5 \\
\hline $\begin{array}{l}\text { has wide } \\
\text { interests }\end{array}$ & & $\mathrm{x}$ & & & $\mathrm{x}$ & $\mathrm{x}$ & & & $\mathrm{x}$ & $\mathrm{x}$ & & 5 \\
\hline $\begin{array}{l}\text { looks for custom } \\
\text { solutions } \\
\text { to problem } \\
\text { situations }\end{array}$ & & & $\mathrm{x}$ & & & & & & $\mathrm{x}$ & $\mathrm{x}$ & $\mathrm{X}$ & 4 \\
\hline $\begin{array}{l}\text { has above ave- } \\
\text { rage social skills } \\
\text { / competences }\end{array}$ & $\mathrm{x}$ & & & & & $\mathrm{x}$ & $\mathrm{X}$ & & & & $\mathrm{X}$ & 4 \\
\hline $\begin{array}{l}\text { is a leader of } \\
\text { a peer group }\end{array}$ & & & & $\mathrm{x}$ & $\mathrm{x}$ & & & & & $\mathrm{x}$ & $\mathrm{X}$ & 4 \\
\hline never gets bored & & & $\mathrm{x}$ & & $\mathrm{x}$ & $\mathrm{x}$ & & & & & $\mathrm{X}$ & 4 \\
\hline $\begin{array}{l}\text { anticipates prob- } \\
\text { lems, difficulties } \\
\text { etc. }\end{array}$ & & $\mathrm{x}$ & & & $\mathrm{x}$ & & & & & & $\mathrm{X}$ & 3 \\
\hline is often bored & & & & & & $\mathrm{x}$ & & & $\mathrm{x}$ & $\mathrm{x}$ & & 3 \\
\hline very ordered & $\mathrm{x}$ & $\mathrm{x}$ & & & $\mathrm{x}$ & & & & & & & 3 \\
\hline $\begin{array}{l}\text { has very narrow, } \\
\text { specific interests }\end{array}$ & & & & $\mathrm{x}$ & & & & & & & $\mathrm{X}$ & 2 \\
\hline very disordered & & & & & & & $X$ & & & & $\mathrm{X}$ & 2 \\
\hline $\begin{array}{l}\text { has a low level } \\
\text { of social skills / } \\
\text { competences }\end{array}$ & & & & & & & & $\mathrm{x}$ & & & & 1 \\
\hline
\end{tabular}




\begin{tabular}{|c|c|c|c|c|c|c|c|c|c|c|c|c|}
\hline Child & 1 & 2 & 3 & 4 & 5 & 6 & 7 & 8 & 9 & 10 & 11 & $\begin{array}{l}\text { Number } \\
\text { of } \\
\text { responses }\end{array}$ \\
\hline $\begin{array}{l}\text { avoids contact } \\
\text { with a peer } \\
\text { group }\end{array}$ & & & & & & & & $\mathrm{x}$ & & & & 1 \\
\hline other & & & & & & & \begin{tabular}{|c|} 
B \\
emphatic
\end{tabular} & & & & & 1 \\
\hline $\begin{array}{l}\text { less physically } \\
\text { developed (than } \\
\text { peers) }\end{array}$ & & & & & & & & & & & & 0 \\
\hline $\begin{array}{l}\text { NUMBER OF } \\
\text { FEATURES PER } \\
\text { CHILD: }\end{array}$ & 9 & 11 & 9 & 8 & 15 & 13 & 12 & 5 & 10 & 13 & 17 & \\
\hline
\end{tabular}

Source: own study

All of the research participants $(\mathrm{n}=11)$ indicated that the "gifted child" selected by them for the study stands out in terms of cognitive functioning and noticing connections between facts and objects. Almost all children (10), in the opinion of educators, are creative, have more knowledge than their peers and have the ability to stay focused, e.g. "a child is interested in things that exceed the capabilities of an average 6 year old. He creates puzzles, tasks, primarily mathematics, looks for unconventional solutions of simple tasks, looks for patterns in tasks, looks for dependencies" (child no. 10). Teachers, when characterizing gifted children, indicated that these children have very good memory and can think abstractly ( 9 indications each). The latter in particular is very rare in four-year-old children, which pays special attention in the case of 4-year-old children. Other features of gifted children, found in the literature, were indicated only several times, although the individual distribution of features shows that 11 children described as particularly gifted differ from one another, sometimes displaying opposite characteristics that might results from their individual and environmental conditions. According to their teachers, only six children "establish, initiate relationships". But only 5 children, age 4 to 6 , show very good skills in solving problems. The same number of children selected for the study have wide range of interests and are curious about the world. Also 5 children were described as more physically developed than their peers, which can be related to the phenomenon of development acceleration discussed earlier. Other indications of teachers further destroy the popular image of a gifted child. Options "never get bored", "is a leader of a peer group" and "presents above average social skills" and "are looking for non-standard solutions to problem situations" were attributed to only 4 children.

The second stage of the research was to obtain in-depth information on the functioning of children selected for the study in the areas discribed in the first part of this research. 
Case 1: the analysis of the results shows that child no. 11 has the highest number of features indicated by the teacher (17 out of 23). According to the educator, this boy (4 years old) has both wide and narrow interests. He is one of the two children surveyed who received an indication of narrow interests. The boy, perceived by the environment as "unruly", "naughty", "easily performs all tasks much faster than other children. He is bored and disorganizes the classes - he focuses on himself. He has extensive knowledge of the world around him. [...]. He is brave and loves experiments. He's all over the place."

The analysis of the family situation shows a large, emotional and organizational involvement of parents in the education and development of their only child. Mature parents (over 40 years old) intentionally organize a wide spectrum of activities, e.g. cinema, theater, museum visits, workshops on various topics, sightseeing trips. "The boy and parents share a very strong bond, they will meet all his needs." In the opinion of the teacher, the child's social development is at a high level, "he likes to dominate and define the rules of play. He knows the rules of functioning in a group and sometimes deliberately breaks them. He observes the behavior of other children and stigmatizes the breaking of rules by others and "complains" to the teacher. Such a strong identification of the boy with the adopted social rules and the behaviors undertaken to maintain the rules can imply strongly developing leadership qualities that only some individuals show in the population. The boy's emotional development allows him to consciously experience feelings and emotions. "[...] he copes well with both positive and negative emotions. Accepts failures." The cognitive functioning of the boy is described by the teacher as "being at a high level." The fast pace of work leads to various embarrassing situations, the boy is bored, disturbs others, "[...] he often answers instead of other children. He hates waiting for his turn. [...] begins to disturb classes, pushes others."

The teacher, when asked about strategies for dealing with behavior issues, provides examples of how she approaches the student. The boy "often plays the role of an expert or assistant during classes. He feels very well in this role." The teacher intentionally adjusts tasks to the individual capabilities of children, so the boy also receives more difficult tasks to meet his cognitive expectations and keep him focused and engaged. Because his interest is piqued, he attempts new activities. Parents, heavily involved in the pre-school life of the boy, having consulted the tutor, enrolled him in many physical activities as well as robotics classes. The boy is extremely physically fit, outperforms all his peers in this respect.

The class teacher, when asked to describe the boy in two words, called him a "bright guy". When making the characteristics of the boy's cognitive development, the teacher emphasized his good memory, ability to use extensive knowledge and new information operatively, he counts well, he manipulates objects perfectly, his art works are creative. He experiments and inquires: "He wants to be constantly active. He himself looks for interesting activities for himself." 
The case study of boy 11 shows that he receives support in all areas of functioning. Good family conditions, attention and commitment of parents, commitment and intentional work of the educator and, above all, the boy's huge potential allow him to be described as a "gifted child" by referring to the three components of Renzulli or his successors.

Case 2: girl (4 years old) no. 8 has the fewest characteristics of a gifted child ( 5 out of 23). All the attributes assigned by the teacher are related to cognitive functioning. They denote his good memory, ability to concentrate, good general knowledge, the ability to see connections between objects or facts, reasoning at a level that exceeds peers. The teacher describes the girl as "intriguing", with above average intelligence, who "does not need a large range of help in acquiring new skills." The girl easily acquires new information. She can read and write now. She works smoothly, faster than her peers. Unlike boy no. 1, the girl "if she finishes early, which often happens, she patiently waits for the other children in the group." She does not look for new, additional activities herself, but usually accepts additional tasks from the teacher, although she sometimes kindly refuses them. The girl comes from a large family, lives in the capital city. Her parents, in the teacher's opinion, meet only the basic needs of the child, "[...] they show a moderate level in terms of educating and upbringing the child."

The girl does not attend any additional activities that would meet her needs. According to the educator, the girl would be helped by music and dance classes, where she could naturally develop emotional expression, courage, belief in her own strength, energy to act. The teacher regrets that the child cannot participate in classes in this area, additionally paid (the girl attends a private kindergarten). The girl is healthy, her physical development is typical of her age. In social contacts, the child "is more an observer than a group participant, preferring to spend time with fewer people who are rather quiet and polite. She [...] tries to avoid outgoing people with expressive ways of showing emotions and experiences." The girl knows, recognizes and expresses emotions, but she does it in a restrained, "not very effusive" way. In the teacher's opinion, the child needs support from the immediate family. She expresses her concern about further education of the girl in this context. She worries the girl will shy away from learning more. Some of the fears of the leading teacher fears the girl needing more attention from her parents may never receive it.

Case 3: selected for individual characteristics, is also a 4-year-old girl who is presented in the study with no. 3. A child who, like the other two, is ahead of her peers' cognitive development, can concentrate, think abstractly, has greater knowledge. "She is characterized by her maturity of expression, a great cause and effect thinking." The girl has a very good memory, "she memorizes very quickly, the pace of work is quite slow [...] she performs all activities at a high level. She does not look for activities herself."

The girl is unable to anticipate problems, difficulties, cannot solve them on her own, reacts very nervously to such situations, needs adult support. The 
girl, according to the teacher, presents a low level of social competence, avoids contact with a peer group, is often bored, "her relationships are limited to selected children in the group, it is very difficult for her to trust strangers." In the emotional development, you can also observe some symptoms of difficulty. The girl "does not cope well with her emotions, often throwing tantrums in situations she finds difficult. However, she shows empathy towards others."

Girl no. 3 has two brothers, an older one with diagnosed Asperger Syndrome and a younger one who does not attend kindergarten yet. The child's parents are very engaged in the girl's situation, in the kindergarten life, "they succumb to the child, they show her a lot of love." During the interview, the teacher points to some features of the Asperger syndrome exhibited by a child who does not like changes that are very difficult for her to accept. She is perceived as "stubborn", she gets easily offended. She is introverted and refuses to participate in some activities. She spends a lot of time reading books alone. The girl attends dance classes, she chose them together with her parents. The girl gave up ceramics classes chosen by her parents. Due to the specific family situation of the child, the educator remains in cooperation with a psychologist, a speech therapist, and also consults with the teaching staff and parents.

The three described cases show one of the many environmental differences between people and at the same time they illustrate the significance of parents, their intentional actions, focus on the child, stimulation of potential, meeting the child's need, by providing interesting, diverse experiences, open expression of positive emotions, etc.

Here the question arises about one of the tasks of the education system consisting in equalizing educational opportunities by pre-school institutions. A limited offer of activities supporting individual talents or interests of a child, eliminating emotional or social problems, leads to the fact that sometimes a teacher is the only person who can intentionally support a gifted child. According to Renzulli's concept, girl no. 8 lacks the so-called behaviors that characterize gifted children, i.e. optimism, courage, passion for a particular topic or discipline, special sensitivity to the needs of others. She also does not show exceptional physical and mental strength, is not a leader, does not present her own visions, ideas, etc.

The considerations and analyses will not determine to what extent the girl's home situation impacts her emotional and social functioning, as compared to boy no. 11. However, they indicate a number of possible fields of impact that a kindergarten could implement, provided that a financial factor would not affect the quality of services. The activities could significantly support the girl's family and above all help her acquire the skills to use her abilities in practice. Perhaps, analyzing the biographies of gifted people, in the Renzulli's definition, a girl subjected to an intentional pedagogical support, equipped, according to the educator's opinion, with above-average intellectual abilities, far ahead of her peers, will develop in the future that will generate her success in life, she will share her gift with the society, 
with peers who show different skills and with those who need support. Case study no. 3 shows the girl's support in preschool, clearly showing the strong emotional and organizational involvement of parents, which confirms the previously thesis about the need for individual, purposeful support of gifted or talented children from important adults. Many children, after all, face many problems, which sometimes concern their health, sometimes the economic conditions of the family, and most importantly, they are primarily children in the face of new development challenges.

\section{Conclusions}

Each of the three children presented in the previous chapter has a unique potential, just like the other 11 children observed in the study. After all, everyone has it. Individual differences are defined from the beginning of life. Pre-school education forms a community, the first group educational environment for the youngest people who achieve the so-called readiness for an independent life outside their homes (toilet skills, eating skills, putting on clothing). The repertoire of the "needs" of the three gifted children that adults can help satisfy, is quite extensive. It will grow with each subsequent child that fits the functioning ability models. I intend to make a hypothesis that attempts to identify gifted individuals, at the pre-school stage, seem justified solely to intensify any possible, individual, intentional influences on the gifted child or (and) their environment (family, teachers, important adults, peer group). The label of a gifted child probably perceived better than the label of a child "with a diagnosis" that some parents are afraid of, given to a child, in my opinion, obliges to take real action to support a gifted child as well. The syndrome of inadequate school achievement, widely described in literature, is a common example of the price paid by bright but also "gifted" children who, under the influence of a certain configuration of factors (internal, external, family, didactic, educational, etc.) significantly lower their academic performance below their potential, they are entangled in social, emotional, functional problems, lose commitment, etc. Pre-school education is the first, and therefore the most important moment of entry into such an organized social environment as is the group of people-children. This is where the child develops their social skills, intensively transforms emotionally, physically changes, perfects their perception, and thus, everything is "new again" for them, expands, constructs their world, referring directly to constructivist learning theories himself (Bruner, 1974).

Research to date has shown that quite often there is a situation in which the teacher identifies a gifted child in a group, but for various reasons, usually organizational settings, they do not provide individual support, focusing their attention and impact on the most needy children, with the lowest scores, the weakest, etc. This is obviously a morally correct decision. As a result, however, gifted children are often left alone, which is manifested, for example, by boredom, inquisitiveness, and 
attempts to gain the attention of a teacher who has to take care of a large group of children with very diverse developmental needs (Kwiatkowska, 2018).

In the educational utopia that I constantly dream about, the issue of identifying gifted children would not take place. The focus would be on strengthening and developing an individual person rather than on a certain category of people (e.g. gifted children). An individual who knows and understands himself or herself and knows how to participate in a group would be at the center of attention. The child is ahead of the group, always with oneself. A smooth transition of a child from the world of egocentrism to an extremely diverse external, social world is the task of good early education, in a way that helps to realize their own potential and respect the individual characteristics of the child (including his abilities and interests).

\section{References}

Bruner, J.E. (1974). W poszukiwaniu teorii nauczania. Warszawa: PIW.

Encyklopedia PWN. Retrieved from: https://encyklopedia.pwn.pl/haslo/akceleracja;4007516.html.

Feldhusen, J.F. (1989). The research on identifying and educating gifted youth supports the use of multiple identification measures, accelerated instruction, and ability grouping. Educational Leadership, 46(6), 6-11.

Gardner, H. (1983). Frames of Mind: The Theory of Multiple Intelligences, New York: Basic Books.

Gardner, H. (2002). Inteligencje wielorakie. Teoria w praktyce. Poznań: Media Rodzina.

Gur, C. (2011). Do gifted Children have similar characteristics? Observation of three children. Procedia Socia and Behavioral Sciences, 12(2), 439-500.

Kwiatkowska, E. (2018). Trudności w pracy z dziećmi z wyzwaniami poznawczymi w percepcji nauczycieli edukacji przedszkolnej. In. E. Śmiechowska-Petrovskij, E. Kwiatkowska (Eds.), Dzieci z trudnościami poznawczymi i emocjonalnymi $w$ młodszym wieku. Teoria $i$ wspieranie. Warszawa: Wydawnictwo Naukowe UKSW.

Limont, W. (2012). Uczeń zdolny. Jak go rozpoznać i jak z nim pracować. Sopot: GWP. Montessori, M. (2005). Domy dziecięce. Warszawa: Wydawnictwo Akademickie „Żak”.

Montessori, M. (2014). Odkrycie dziecka. Łódź: Palatum.

Oświata i wychowanie, w roku szkolnym 2017/2018 (2018).Warszawa, Gdańsk: GUS.

Papadopoulos, D. (2016). Psych-pedagogical and educational aspects of gifted students, starting from preschool age. How can theis needs be best met? Journal of Psychological Abnormalities, 5(2).

Piaget, J.(1981). Równoważenie struktur poznawczych. Warszawa: PWN. 
Renzulli, J.S. (2005). The three-ring conception of giftedness. A development model for promoting creative productivity. In R. J. Sternberg \& J. E. Davidson (Eds.), Conceptions of giftedness (pp. 246-279). Cambridge: Cambridge University Pres.

\section{DZIECKO ZDOLNE W PRZEDSZKOLU - PUŁAPKI DIAGNOZOWANIA}

Streszczenie: W artykule podjęto problem identyfikacji (diagnozy) dzieci zdolnych w odniesieniu do wybranych teorii zdolności. Specyfika dziecka we wczesnym dzieciństwie nie wyklucza, że dziecko zdolne, rozumiane potocznie jako inteligentne, $\mathrm{z}$ dużymi możliwościami poznawczymi, w przyszłości, w wyniku niekorzystnych oddziaływań środowiskowych, zbiegu wydarzeń porzuci, zaniecha swój wrodzony, unikalny potencjał, wikłając się przy tym w różnego rodzaju „problemy”, nabierając cech wskazujących na syndrom nieadekwatnych osiągnięć szkolnych i in. Przedstawione w artykule indywidualne studia przypadków mają na celu zobrazowanie znaczenia indywidualnych oddziaływań na dziecko zdolne w wieku przedszkolnym, ze względu na szczególną specyfikę rozwojową tego okresu.

Słowa kluczowe: dziecko zdolne; dziecko utalentowane; przedszkole; nauczyciel edukacji przedszkolnej; diagnoza. 